Article

\title{
Social Sustainability: A New Conceptual Framework
}

\author{
Efrat Eizenberg and Yosef Jabareen * \\ Faculty of Architecture and Town Planning, Technion, Israel Institute of Technology, Haifa 3200003, Israel; \\ efrate@technion.ac.il \\ * Correspondence: jabareen@technion.ac.il; Tel.: +972-548-045-125 \\ Academic Editor: Marc A. Rosen \\ Received: 5 October 2016; Accepted: 29 December 2016; Published: 5 January 2017
}

\begin{abstract}
There is a lack of theoretical and empirical studies regarding social sustainability. The literature reveals that the "social" was integrated late into debates on sustainable development. This paper aims to fill this gap and proposes a new conceptual framework of social sustainability. We suggest that risk is a constitutive concept of sustainability and that the contemporary conditions of risk resulting primarily from climate change and its ensuing uncertainties pose serious social, spatial, structural, and physical threats to contemporary human societies and their living spaces. Within the framework of sustainability, we propose that social sustainability strives to confront risk while addressing social concerns. Although we agree that without socially oriented practices, efforts to achieve sustainability will be undermined, as too many gaps exist in practice and theory. Thus, we propose a comprehensive Conceptual Framework of Social Sustainability, which is composed of four interrelated concepts of socially oriented practices, where each concept has a distinctive function in the framework and incorporates major social aspects. The concept of Equity encompasses three dimensions: recognition, which "revalues unjustly devalued identities", redistribution, which suggests that the remedy for injustice is some form of economic restructuring, and parity of participation, which promotes substantive public involvement in the production of space. These efforts may, in turn, reduce alienation and enhance civility and a sense of community and place attachment. The concept of Safety is the ontological foundation of sustainability in general and social sustainability in particular. The concept refers to the right to not only be safe but adopt all measures of adaptation and security to prevent future casualties and physical harm. The concept of Eco-prosumption refers to modes of producing and gaining values in socially and environmentally responsible ways. The concept of Urban Forms represents the physical dimensions of socially desired urban and community physical forms. Eventually, a desired physical form should promote a sense of community, safety, health, and place attachment, among other environmental objectives.
\end{abstract}

Keywords: social sustainability; sociology; justice; risk; safety; mitigation; adaptation; energy; consumption; right to the city

\section{Introduction}

The "social" was integrated late into debates on developing sustainability. Within the social sciences, the discipline of sociology has been invisible in professional circles, and public and policy discussions have focused on climate change and sustainability [1,2]. However, other disciplines, such as geography, urban studies and planning, and anthropology, have been more involved. As the relatively brief history of this debate suggests, the central narrative initially concerned saving endangered species and unique ecosystems and, thus, advanced a harsh critique of the treatment of nature by humans. When technologically-centered thinking on sustainability became more prominent, the scope of the debate extended beyond wild nature to include urban environments. Theory and practice centered on technological innovations to reverse climate change and protect planetary resources from overuse, while enabling the continual consumption of these resources. 
Only with the widening influence of the social ecology framework that was enhanced by ecofeminist, ecosocialist, indigenous movement theories did the debate shift toward an understanding that most of humanity is vulnerable when facing environmental externalities, natural disasters, and climate change. Moreover, the sustainability discourse was linked to the inequality discourse when it became apparent that environmental externalities are differentially and disproportionally distributed, both geographically and among groups [3]. The major challenges of today are framed within the social context with the mounting levels of evolving risk and vulnerability resulting from social polarization, rising urban poverty levels, urban conflict and violence, terrorism, natural disasters, and climate change [4]. These challenges affect planning and practices, thus necessitating the rethinking and revision of current planning methods to remedy this dire social situation $[4,5]$.

It is accepted that a triad model, in which the ecological is interwoven with the economic and the social, is required to formulate methods of sustainable development [6,7]. This three-pillar model of sustainability has greatly evolved in developing each aspect independently. However, as Littig and Greissler [8] assert, no conclusive understanding of the relationship between the elements of the triad, or of how they should be measured and evaluated, was formulated.

Although developing this understanding has dramatically altered the "sustainability" discourse, one aspect of the discourse, namely social sustainability, lacks a coherent, clear and utilizable definition [9]. The deficiencies are typically attributed to social scientists, who are criticized for being conceptually vague and inconsistent, thus generating multiple concepts $[10,11]$. Furthermore, Grieller and Littig [12] found that even the selection of social sustainability indicators frequently is not grounded in theory but rather in a practical understanding of plausibility and current political agendas.

A deeper, ontological caveat of the ambition to overcome the convulsive and feinted discourse on social sustainability is proposed by Boström [13] and Davidson [14], who contend that any effort to develop socially sustainable communities entails first the need to define the "kind of society ... we want to sustain" [13] (p. 12); [14] (p. 609). Although drawing the contours of a just society is too ambitious by far and beyond the scope of this paper, we would like to offer some progress by following two propositions: first, that the main problem with the contemporary scattered framework does not concern defining the social circle of sustainability but in approaching sustainability through three dimensions while endeavoring to define each dimension separately. Second, we understand risk as a dominant organizing concept and the manner in which societies cope with or ignore risks as a determent (though not solely) of social injustices [4,12,15-17]. Thus, by positioning risk as a constitutive concept of sustainability, we re-conceptualize social sustainability within the vision of having a safer planet: safer human and non-human societies now and in the future. Therefore, our goal in this article is to review existing definitions concerning the social aspects of sustainability, outline the deficiencies and problems of contemporary understandings of sustainability and offer an alternative conceptual framework for social sustainability. The proposed framework aims at redefining and redirecting policies of coping with risk to facilitate resilient societies.

\section{Definitions of Social Sustainability: The Dearth of Theory}

Vallance et al. [11] suggest that social sustainability research tends to be anchored in the 1987 Brundtland Report, Our Common Future. This report defines sustainable development in a way that emphasizes human livelihoods as integral to accomplishing ecological goals though economic development that "meets the needs of the present without compromising the ability of future generations to meet their own needs" [11].

The UK Sustainable Communities document [18] (p. 5), approved in 2003, defines sustainable communities as "places where people want to live and work, now and in the future. They meet the diverse needs of existing and future residents, are sensitive to their environment, and contribute to a high quality of life. They are safe and inclusive, well planned, built and run, and offer equality of opportunity and good services for all". While this definition foregrounds social equity and justice by referring to diverse needs, inclusion criteria, and opportunities, careful reading exposes a privilege of the physical environment and of 
how community settings enable sustainable social outcomes. Alternatively, as Dempsey et al. [19,20] observed, this definition emphasizes "the close relationship between the neighborhood itself and the people living within it".

Adopting this perspective, the existing literature on sustainability associates various physical factors with social sustainability. For example, Jabareen [21] associates social sustainability outcomes with urban planning and design principles, such as compactness, mixed use, density, sustainable transport, and greening. Dempsey et al. [19] enumerate physical factors that they associate with sustainability, such as urbanity, an attractive public realm, decent housing, local environmental quality and amenities, accessibility, sustainable urban design, neighborhoods, and walkable neighborhoods (i.e., pedestrian friendly neighborhoods). Most of these factors are tangible and measurable and can, therefore, be readily evaluated for successful planning. Importantly, however, good planning principles can be associated with many of these factors without contributing to social sustainability; in fact, they may support unsustainable outcomes. For example, some of these principles, such as walkability, became buzzwords for creating a desired urban atmosphere to attract a stronger population to cities or particular urban neighborhoods, fueling gentrification.

As important as they may be for achieving social sustainability, physical settings/characteristics are insufficient for addressing the problems that urban communities currently face, and cannot independently generate the capacities that communities require to become sustainable. Additional characteristics are important for achieving social sustainability, including necessary social processes and structures that will emerge within a community and ensure the satisfaction of its needs, which are ever-changing. Hence, Vallance, Perkins, and Dixon [11] suggest that we should understand the processes and structures of social sustainability as occurring and needing to proceed through the following three approaches: 'development sustainability'; 'bridge sustainability', which ensures that structures are modified to satisfy changing needs; and 'maintenance sustainability', which ensures the preservation of useful and working structures. Coleman [22] (p. 94) suggests the following: "sustainability of community relates to the ability of society itself, or its manifestation as local community, to sustain and reproduce itself at an acceptable level of functioning in terms of social organization $[\ldots]]^{\prime \prime}$.

In terms of these approaches, the literature provides a lengthy list of non-physical factors corresponding to the named social processes and structures. Jabareen [21] stresses diversity as the constitutive process ensuring social sustainability. Dempsey et al. [19] (p. 291) specified a comprehensive list, which includes education and training; inter- and intra-generational social justice; participation and local democracy; health, quality of life and well-being; social inclusion (including the eradication of social exclusion); social capital; community; safety; mixed tenure; fair distribution of income; social order; social cohesion; community cohesion (i.e., the cohesion of groups); social networks; social interaction; sense of community and belonging; employment; residential stability (vs. turnover); active community organizations; and cultural traditions. Dempsey et al. [19] also highlighted the pride/sense of place attachment and community stability. Other scholars have expressed similar or related factors in slightly different terms [23-25]. Notably, all of these non-physical factors are more difficult to grasp compared to their physical counterparts and are likewise more difficult to implement through planning and policy. Accounting for non-physical factors is more difficult because social processes and structures are dynamic, impossible to anticipate or at least involve unanticipated developments, are difficult to enforce and control in non-dictatorial ways and are not suitable for everyone. The greatest challenge, though, is likely the fact that success is difficult to identify and measure. To attempt to address the limited capacity of indicators to measure the success of sustainable policy, proposed a way of thinking about indicators that will "help cities and regions became adaptive learning systems" toward developing sustainable communities. Their tripartite strategy includes indicators for environmental performance, 'system performance indicators'; indicators of the impact of sustainable policies and programs, 'policy and programs indicators'; and ongoing feedback from community members that focuses on the changes, challenges 
and achievements enabled by policy actions. However, their approach did not overcome the difficulties of measuring different social processes, which are considered in the literature as a target output of social sustainability.

Given these difficulties, how do planning and policy actions strive to address these factors affecting sustainability outcomes? How does planning facilitate the ability of a community to develop processes and structures that not only satisfy the requirements of current members but also support the ability of future generations to maintain a sustainable community? Since the communicative turn in planning in the 1970s [26-30], good, just, equitable planning processes are associated with public participation in planning. Public participation in planning became the preferable approach to planning and a mostly generic response to several social challenges and vagaries, including sustainability.

The communicative theory has been criticized from both outside the discipline as insufficiently radical [31] and within the discipline as foundationally flawed [23]. Various mechanisms for public participation in planning were invented and unsuccessfully applied over more than four decades [23-25]. Some of the more progressive mechanisms of public participation in planning have yielded positive results, such as improved social cohesion and the development of social networks that allow people to discuss problems and solutions together and become acquainted with each other [24]. Nevertheless, most methods for participation, even the more innovative, time-consuming, resource-intensive methods, have been deemed failures. They do not promote local democracy, residents mostly do not feel that their voices were heard, and the outcomes of these processes do not address the needs and demands of the public [23-25,30].

Explanations for the failures of such methods suggest that planners do not know how to translate communities' needs and demands into planning decisions, including integrating the needs and demands in plans and manifesting them in urban redevelopment. Additionally, these processes do not change processes of local decision-making and the reality that those in power are unwilling to relinquish their position of control over decision-making, despite initiating the public participation process [23-25,30,32].

Finally, another impediment to public participation is the nature of these public participation processes. Being temporal and problem- or project-oriented, the processes undercut their potential to generate sustainable outcomes. Hence, as commonly understood, public participation does not support the development of local/community organizations, namely the social structures required to address dynamic social issues. Thus, the most popular approach to the "social", including the tools attached to it, seems generally counterproductive and particularly so in promoting social sustainability.

The dissociation between the social and the ecological and economic leaves the social undefined, inapplicable and utopian, thus impossible to fulfill, control and facilitate, at least not through planning practices. We would, therefore, like to suggest an alternative conceptual framework that integrates the physical and non-physical aspects of social sustainability. Our framework also aims to interlink the social and the ecological and economic aspects of sustainability.

\section{Methodology}

Our theorization of social sustainability is based on the conceptual analysis method of Jabareen [33]. This method is a grounded theory technique that aims to "generate, identify, and trace a phenomenon's major concepts, which together constitute its theoretical framework" [33]. Each concept possesses its own attributes, characteristics, assumptions, limitations, distinct perspectives, and specific function within the conceptual framework. The methodology delineates the following stages in the building of a conceptual framework: (a) mapping multidisciplinary data sources; (b) reviewing the literature and categorizing the selected data; (c) identifying and naming the concepts; (d) deconstructing and categorizing the concepts; (e) integrating the concepts; (f) synthesis, re-synthesis, and making it all make sense; and ( $\mathrm{g}$ ) validating the conceptual framework. The process of construction of the conceptual framework involves extensive review and classification of the literature that addresses environmental, social, cultural, and urban aspects of sustainability. This literature comes from a variety 
of disciplines and fields of study, such as: urban planning sociology, anthropology, public policy, political science, economics, and ecology.

Accordingly, this paper conceptualizes social sustainability as a theoretical plane of interlinked concepts that together provide a comprehensive understanding. This conceptual framework is not merely a collection of concepts, but, rather, is a construct composed of consistent concepts in which each plays an integral role and is intrinsically linked to the other.

Furthermore, we reflect predominantly on climate change as a sustainability challenge. The concept of sustainability has dominated the environmental literature in the last three decades, mainly since the Brundtland Commission in 1987. However, in recent years, the world and the interdisciplinary literature become widely aware of the "climate change" and its impact following the Intergovernmental Panel on Climate Change (IPCC), mainly in 2007. For us, climate change represents the mounting risk and threats for our societies and planet, while sustainability represents the social, economic, environmental policies and measures needed for coping with these risks and threats.

\section{The Conceptual Framework of Social Sustainability}

\subsection{Risk as the Ontological Foundation of Sustainability and Social Sustainability}

Following the seminal works of Risk Society by Beck, Giddens and Lash [15-17] and The Risk City by Jabareen [4], we suggest that risk is a constitutive concept of sustainability and that the contemporary conditions of risk resulting primarily from climate change and its ensuing uncertainties pose serious social, spatial, structural, and physical threats to contemporary human societies and their living spaces.

Anthony Giddens and Ulrich Beck conceptualize both modernity and modern societies as a function of risk. In his seminal book, The Risk Society, Beck [15] defines the "risk society" in terms of risks that have emerged since the 1960s. "Modern society", he maintains, "has become a risk society in the sense that it is increasingly occupied with debating, preventing and managing risks that it itself has produced" [17] (p. 332). From his perspective, this concept was "an inescapable structural condition of advanced industrialization". The theory of the world risk society, however, maintains that modern societies are shaped by new types of risks and that their foundations are shaken by the worldwide anticipation of global catastrophes. Such perceptions of global risk are characterized by three features [17] (p. 334): (1) spatial, as reflected in the fact that many new risks (such as climate change) do not recognize the borders of nation-states and other such entities; (2) temporal, as manifested in the long latency period that is characteristic of new risks (such as nuclear waste), making it impossible to effectively determine and limit their effects over time; and (3) social, as exhibited in the complexity of the problems and the length of the chains of effect, which means that it is no longer possible to determine causes and consequences with any degree of reliability (as in the case of financial crises). Convincingly, Beck [17] (p. 3) suggests that risk is "the modern approach to foresee and control the future consequences of human action".

Following Beck and Giddens, The Risk City, argues that, to a certain extent, cities have always coped with risk, as reflected in the following words penned by Aristotle more than two millennia ago: "Men come together in cities for security; they stay together for good life" [34] (p. 139). With the rapid development of technology and modernity, this aspect of cities has intensified greatly, as reflected in their increasing occupation with interrogating, estimating, preventing, managing, accepting, denying, and seeking to manipulate and cope with risks. Indeed, cities have been facing environmental, health, social, and security threats for centuries, and have always strived to reduce risks by various spatial, physical, social, and environmental measures. Convincingly, Giddens [35] uses the term "double hermeneutic" to refer to the observation that "when scientific concepts become generally accepted as a means of making sense of the society, they not only reflect but also construct social practices" [36] (p. 14). 
Scientists from various disciplines agree that the destructive impact of the risk and uncertainties related to climate change (both those we can anticipate today and those that remain unknown) are likely to increase in the near future. Others argue that climate change, with its catastrophic impacts, is already underway [37-39]. Climate change, it is argued, will affect urban security and will threaten the well-being, safety, and survival of urban residents, and its effects will continue to deepen and spread the incidence of poverty among various urban low-income groups. Consequently, in recent years, tens of thousands of people have experienced intensifying environmental risks and threats. Concomitantly, the social and material infrastructures supporting human life have been severely impacted in urban environments throughout the world. Clearly, contemporary cities and their residents are facing phenomenal and mounting levels of evolving risk and vulnerability because of climate change [37-39], which affect the social, economic, ecological, and physical systems and assets of every city [4].

Therefore, a primary aspect of the risk city is its construction of sociopolitical and spatial practices and frameworks aimed at responding to these uncertainties and countering the worst of them. In this respect, the response is about "structural arrangements", "emergency planning", prevention, mitigation, and adaptation. Thus, we contend that the concept of risk is the main fundamental theoretical premise of sustainability in general and its social aspects in particular, and it is therefore constitutive of our proposed conceptual framework of social sustainability. Within the framework of sustainability, we propose that social sustainability comprises socially oriented practices intended to address major social issues to cope with the risks of climate change and environmental hazards. In other words, social sustainability strives to confront risk while addressing social concerns. Although we agree that without socially oriented practices, efforts to achieve sustainability will be undermined, and too many gaps exist in practice and theory. Thus, we propose a comprehensive Conceptual Framework of Social Sustainability (CFSS), which is composed of four interrelated concepts of socially oriented practices, where each concept has a distinctive function in the framework and incorporates major social aspects as follows.

\subsection{Equity}

Equity, or justice, inclusively addresses social, environmental, and economic justice and fairness issues in all developing and developed societies. In our social sustainability framework, the fundamental premise of equity and justice is that less inequality and greater justice reduce the alienation of people from their living spaces and, thus, heighten their concern with environmental issues. Therefore, the concept of equity emphasizes social and economic justice, fairness in pursuing sustainability policies and development while addressing climate change [37-42].

Equity is among the most known representatives of social aspects within the sustainability literature [43]. The interdisciplinary literature of sustainability and climate change suggest that the impacts of climate change and other risks are not evenly distributed but are "socially differentiated". Because risks are matters of local distributional equity and justice [43-47], resilience resources are evidently unequally distributed [48-52]. Furthermore, there are individuals and groups within all societies that have insufficient capacity to adapt to climate change. "Vulnerability to climate change refers to the propensity of human and ecological systems to suffer harm and their ability to respond to stresses imposed as a result of climate change effects" [45] (p. 720). Notably, the vulnerability of a society is influenced by its development path, physical exposures, the distribution of resources, prior stresses, social networks, government institutions, and technology [45] (pp. 719-720). Advancing this perspective, Mohai, Pellow, and Roberts [53] claim that climate change actually increases social inequality, and that adaptive and resilience resources have apparently been distributed unequally, as demonstrated by the aftermath of Hurricane Katrina in the United States.

Furthermore, climate change injustice occurs along ethnic, gender, class, and racial lines $[42,53]$ and can emerge among neighborhoods and communities in any developed and developing society. Within all societies, certain individuals and groups are particularly vulnerable, lacking the capacity to adapt to climate change [54] (p. 719). Demographic variables affect the ability of individuals 
and urban communities to cope with environmental risk and future uncertainties through risk mitigation, response, and recovery in the event of natural disasters [55,56]. The degree of vulnerability is influenced by several factors; the most important of which are income, education and language skills, gender, age, physical and mental capacity, accessibility to resources and political power, and social capital $[55,56]$. Some argue that the opposite relations are true, namely that inequality causes greater environmental degradation and that a more equitable distribution of power and resources would improve environmental quality [57]. Additionally, the communities most vulnerable to climate change typically live in the most vulnerable, high-risk locations and may lack required skills and adequate infrastructure and services [58].

Furthermore, Laura Pulido [59] contends that various forms of racism contribute to environmental racism and inequality. Specifically, in urban areas, land use allocations, zoning policies, patterns of residential, industrial, and economic development, are sources of environmental inequality [59]. Dunion contends that "environmental injustice is experienced as a result of practices or policies, which, intentionally or unintentionally, disparately impact the living conditions of people in low-income groups" [60] (p. 12). Therefore, a more equitable distribution of power and resources contributes to improvement in environmental quality and reduces injustice, whereas greater inequality leads to greater environmental degradation $[57,61]$.

Following the recent literature on environmental and social justice and sustainability, we conclude that the concept of equity, or justice, is a central component of the social sustainability framework. This concept includes three dimensions:

a. Redistributive: "The politics of redistribution focuses on injustices it defines as socioeconomic and presumes to be rooted in the economic structure of society", as Fraser put it [62] (p. 6). These injustices include but are not limited to economic marginalization, or deprivation, and being denied an adequate material standard of living [62] (p. 7). Thus, the politics of redistribution suggest that the remedy for injustice is economic restructuring of some sort. Such efforts might involve redistributing income, reorganizing the division of labor, or transforming other basic economic structures [62] (p. 8). Furthermore, the distribution of environmental beneficiaries (e.g., access to clean energy) and environmental hazards (e.g., pollution) are unfairly distributed among different groups [48]. Therefore, this concept suggests that social distributive justice entails ensuring that people have various rights, such as the right to energy, the right to adequate standards of living, and the right to clean air, water, and related resources.

b. Recognition: Vulnerable groups in all countries not only bear a disproportionate share of both environmental burdens, benefits and opportunities but also lack recognition and the voice of the disadvantaged and the vulnerable in policies that determine their lives [59,62-66]. Significantly, social sustainability endorses politics of recognition, which encompass policies aiming "to revalue unjustly devalued identities", and to deconstruct tendencies, such as queer politics, critical "race" politics, and deconstructive feminism, which reject the "essentialism" of traditional identity politics. Therefore, equity policy should be concerned with the principles and outcomes of social, economic, and environmental policy decisions and the ensuing effects on different social and ethnic groups [48].

c. Participation: We propose that participatory justice is significant for developing human spaces that favorably reflect the efforts of sustainability. Following Fraiser [62] (pp. 30-31), we suggest that her concept of parity of participation, which assumes that "justice requires social arrangements that permit all (adult) members of society to interact with one another as peers", is crucial for achieving social sustainability. For participatory parity to be possible, Fraiser contends that it is necessary to establish standard forms of formal legal equality. Furthermore, two conditions must be satisfied: (1) the distribution of material resources must be such that it ensures participants' independence and "voice" to preclude forms and levels of material inequality and economic dependence that impede parity of participation; (2) "intersubjectivity" must be realized, which "requires that institutionalized cultural patterns of interpretation and evaluation 
express equal respect for all participants and ensure equal opportunity for achieving social esteem. This precludes cultural patterns that systematically depreciate some categories of people and the qualities associated with them" [62] (p. 31). Participation also concerns "meaningful involvement" in environmental decision-making processes, and the production of a space based on the conception of the people concerned, who should be allowed to produce it as their "heart's desire" rather than as an understanding imposed on them by the state, the local government, experts and planners [63,67]. Parity of participation bolsters procedural justice through participation and space envisioning, thereby allowing communities to produce more environmentally sound places through their visions and desires. In other words, justice entails not only securing a fair distribution of goods but also recognizing the membership of people in the moral and political community and promoting the capabilities required for the functioning, flourishing, and protection of the people [67].

Furthermore, the literature on sustainability emphasizes the two aspects of equity: intergenerational and intragenerational equity. Both aspects are significant for social sustainability. Intergenerational equity refers to fairness in allocating resources between current and future generations. An early formulation by Robert Repetto [68] (p. 10) proposed that "at the core of the idea of sustainability, then, is the concept that current decisions should not damage the prospects for maintaining or improving living standards in the future... This implies that our economic systems should be managed so that we live off the dividend of our resources, maintaining and improving the asset base so that the generations that follow will be able to live equally well or better". For Robert Solow [61] (p. 3), sustainability is simply a matter of distributional equity, about sharing the capacity for well-being between present people and future people. Intragenerational equity refers to fairness in allocating resources b62etween competing interests at the present time.

Importantly, the demand for equity, social, economic and environmental justice is for all people regardless of their origin, race, gender, ethnicity, color, minorities, citizenship status, local and immigrants, and developed and developing societies. Under the prism of social sustainability, the cry for equality for all, including the welfare of following generations, is fundamental for coping with climate change and environmental crisis.

\subsection{Safety}

The concept of safety is among the ontological foundations of our social sustainability framework. This concept concerns the rights to be protected and secured in situations of vulnerability. Social sustainability must address the critical requirements of a society to be protected and secured when experiencing environmental and climate change vulnerability. Vulnerability refers to the "degree to which a system is susceptible to, and unable to cope with, adverse effects of climate change, including climate variability and extremes" [69] (p. 61). A society's vulnerability is influenced by its development path, physical exposure, resource distribution, social networks, government institutions, and technological development [37]. It is important to acknowledge that in all societies, certain individuals and groups are more vulnerable than others are and lack the capacity to adapt to climate change and environmental hazards [70]. Accordingly, safety, or as we propose, the right to safety, is a right of all individuals and groups, regardless of such characteristics as gender, health, age, and race.

Therefore, to ensure the safety of individual and communities, adequate corresponding adaptation measures are required. Adaptation entails "controlling uncertainty-either by taking action now to secure the future or by preparing actions to be taken in case an event occurs" [71] (p. 237). Furthermore, adaptation in human systems is defined as the process of adjusting to actual or expected climate change and its effects in terms of moderating harm or exploiting beneficial opportunities [37,38,72]. That is, this right includes the right to be protected in the future and during hazard events by adopting adequate measures of protection and adaptation. When we adopt adaptation measures, we acknowledge that the climate will continue to change and that we must reduce risks [73]. From this perspective, climate change adaptation should be considered indispensable [72]. 
To enhance the right to safety for each community and neighborhood, understanding the socio-spatial settings of risk or vulnerabilities of a city and community is crucial for more effectively coping with risk and achieving more than just policies for the most vulnerable populations. We suggest the approach of Urban Vulnerability Matrix (UVM), which is a framework for analyzing the social-spatial distribution of vulnerabilities in a city and the adaptation measures. It provides significant information regarding risks and uncertainties for a city, communities, and social groups [4]. The UVM allows us to understand in-depth the distribution of risk and uncertainties and the existing and planned adaptation measures for a city. The Urban Vulnerability Matrix is crucial for the sustainable and resilient city and its contribution to the spatial and socio-economic mapping of future risks and vulnerabilities [4]. The role of the UVM is to analyze and identify the types, demography, intensity, scope, and spatial distribution of environmental risk, natural disasters, and future uncertainties in a city and its neighborhoods and communities. Significantly, UVM is also a tool for improving environmental and social justice. When we acknowledge and analyze the distribution of vulnerabilities across neighborhoods and communities and the existence of adaptation measures, we can also determine the conditions of vulnerability and adaptation for minority, immigrant, and poor communities. Additionally, UVM improves our understanding of risk and uncertainty complexity at the community and city levels. It can help us model scenarios of city futures for the purposes of planning adaptation measures and coping with threats [4].

\subsection{Sustainable Urban Forms}

The theoretical hypothesis supporting sustainable urban forms suggests that the physical aspects of human spaces, now and in the future, are crucial for achieving social sustainability, mitigating environmental risk, and enhancing human well-being and welfare. Sustainable human spaces address the question concerning the nature of the desired physical spaces, places that address social issues within the wider sustainability framework. The issue of urban form is crucial for achieving urban sustainability and coping with risk. The urban form of the risk city should be re-conceptualized as a concept not only of sustainability but also of risk, mitigation, and adaptation. The form of the contemporary city itself has been perceived as a source of environmental problems [4,21,48,49,74,75], and urban planning may play a vital role in both the mitigation and adaptation of climate change [76]. In Our Built and Natural Environments [48], the U.S. Environmental Protection Agency (EPA) concludes that the urban form directly affects habitats, ecosystems, endangered species, and water quality through land consumption, habitat fragmentation, and the replacement of natural cover with impervious surfaces. Additionally, the urban form affects travel behavior, which, in turn, affects air quality; the premature loss of farmland, wetlands, and open spaces; soil pollution and contamination; global climate; and noise pollution [77,78].

Because of its function in the context of the safety and the protection of inhabitants from disasters and threats, urban form and its physical typologies play an important role in achieving sustainability. It should, therefore, be oriented toward enhancing safety and promoting a sense of community, place attachment, sense of safety, and healthy communities. Furthermore, the urban form should help mitigate and cope with climate change, uncertainty, and various risks [4,21].

Jabareen [21] suggested a set of typologies to help understand how different features of the urban form impact the practices of risk in general and mitigation policies in particular:

a. Compactness refers to urban contiguity and connectivity and suggests that future urban development should occur adjacent to existing urban structures $[79,80]$.

b. Sustainable Transport promotes sustainable modes of transportation through traffic reduction, trip reduction, the encouragement of non-motorized travel $[77,78]$.

c. Density, the ratio of people or dwelling units to land area, affects climate change through differences in the consumption of energy, materials, and land for housing, transportation, and urban infrastructure [49]. 
d. Mixed Land Uses refers to the diversity of functional land uses, such as residential, commercial, industrial, institutional, and transportation uses [74,81,82].

e. Diversity promotes other desirable urban features, such as a greater variety of housing types, building densities, household sizes, ages, cultures, and incomes [83] (p. 320). Diversity is vital for cities, without which the urban environment declines as a living place [84], and the resulting homogeneity of built forms, which often produces unattractive monotonous urban landscapes, increases segregation, car travel, congestion, and air pollution [80].

f. Passive Solar Design aims to reduce energy demands and to optimize the use of passive energy through specific planning and design measures $[85,86]$.

g. Greening, or bringing "nature into the city", positively affects several aspects of the urban environment, including biodiversity, the inhabited urban environment, urban climate, economic attractiveness, community pride, and health and education $[87,88]$.

h. Renewal and Utilization refer to the process of reclaiming the many sites that are no longer appropriate for their original intended use and that can be used for a new purpose, such as brownfields.

These typologies compose the structure of the desired sustainable urban form, which can enhance the social aspects of neighborhoods and communities, such as the sense of community, place attachment, and healthy community while supporting the environmental agenda to promote mitigation and adaptation measures for neighborhoods and communities.

\subsection{Eco-Prosumption}

Reorganizing prosumption practices as eco-friendly and community-oriented is a crucial risk-mitigation effort. Mitigation refers to an "action to reduce the sources (or enhance the sinks) of factors causing climate change, such as greenhouse gases" [89] (p. 61) and to "the reduction of GHG emissions and their capture and storage to limit the extent of climate change" [90] (p. 2). These measures aim to help reduce the environmental risk posed to the city and community and to assist with the global effort to counter climate change. Here, we expend mitigation efforts to further include the reduction of social risks such as exploitation, alienation and scarcity. Some scholars [91,92] conceptualize prosumption as the acts of production and consumption, which are tightly intertwined and inseparable. Prosumption that characterizes the capitalist mode of production became more dominant, the authors argue, in late capitalism with the wide spread of information technologies (IT) [93]. The idea that a consumer is at the same time producing an exchange value or that many individual consumers are in fact (and even without coordination) co-producing value [93] is an important organizing concept for rethinking how contemporary modes of production and consumption can transform into a sustainable mode of prosumption. Eco-prosumption refers to modes of consuming, producing and gaining values in socially and environmentally responsible ways. The concept may include numerous known measures of production/consumption in sustainable ways, such as reduced energy consumption, clean energy use, recycling, the use of non-motorized travel such as walking and cycling and other friendly modes of transportation. However, new, more complex and collaborative mechanisms of prosumption that are either community-based or IT-based, or both, are already practiced and discussed in the literature. The rich discussion on the reorganization of production and consumption in cooperative rather than competitive ways at times addresses sustainability directly and other times focuses more on poverty alleviation or egalitarian ends. In addition, these practices and visions or imaginaries are sometimes conceived as revolutionary, posing an alternative to the neoliberal mode of consumption and production [94], and sometimes as an evolutionary state of the capitalist mode of production, giving way to a better, more humane as well as environmental friendly stage $[95,96]$. Examples of these practices and vision can be found in the concepts and practices of community economies, in alternative local gardening and food systems [97-100] in cooperative models of housing, workplaces, banking and financing, and consumption [101], and in various models of operation in the established movement of 
transition towns [102]. These diverse and newly evolving modes of economic organization, which we refer to as Eco-prosumption, in fact facilitate both environmental and social resilience of communities and therefore complete our quadruple framework.

\section{Conclusions}

This paper proposed a conceptual framework for social sustainability that seeks to enhance the protection of people, all people regardless of color, origin, culture, or socio-economic status, against risk by fostering the adaptation of just and equitable social, economic, and environmental policies. This conceptual framework reframes a vision toward a more sustainable future, which is critical for achieving sustainability objectives in general. The power of this social sustainability thinking is its inherent ability to view the future in terms of radically new forms and values (see [103]). This framework articulates an alternative set of arrangements and constructs to urge others to act in concert to affect change (see [104]).

The main theoretical premise of this framework is that social sustainability is part of a wider framework for sustainability that strives to cope with environmental and climate change risk. The framework strives to understand the social sustainability as an integration of social, economic and ecological aspects. The conceptual framework for social sustainability is a construct of four interrelated concepts as appears in Figure 1. Each performs a specific function within the social sustainability framework. The theoretical contribution of this social sustainability framework lies in its ontological approach, making risk a constitutive concept of sustainability thinking and practices. Risk conditions, resulting primarily from climate change and its ensuing uncertainties, pose serious social, spatial, structural, and physical threats to contemporary human societies and their living spaces. Within the framework of sustainability, we propose that social sustainability comprises socially oriented practices intended to address major social issues to cope with risks of climate change and environmental hazards.

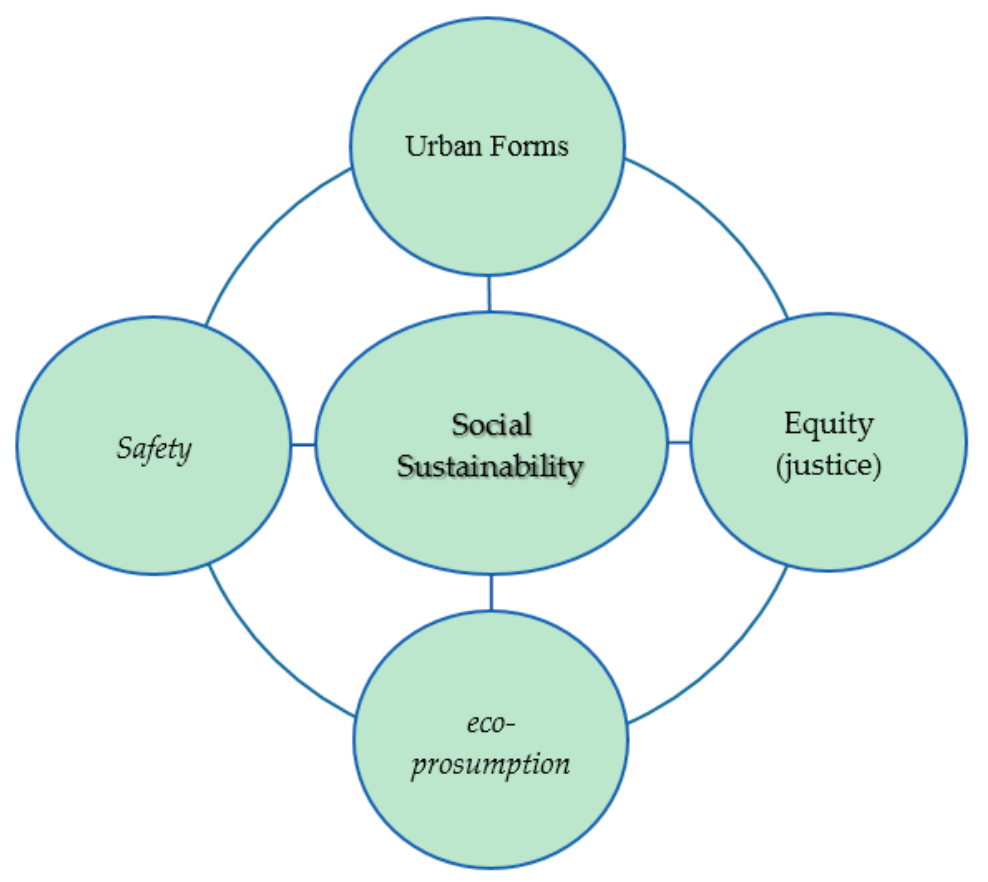

Figure 1. Concepts of social sustainability.

Table 1 outlines the conceptual framework and its main concepts, including their theoretical premises and components. The concept of equity seeks to prevent unequal policies and to promote substantive public involvement in the production of space. These efforts may, in turn, reduce alienation and enhance civility and a sense of community and place attachment. The concept of safety is the 
ontological foundation of sustainability in general and social sustainability in particular. It refers on the right to not only be safe but adopt all measures of adaptation and security to prevent future casualties and physical harm. The concept of Eco-prosumption refers to modes of consuming, producing and gaining values in and towards socially and environmentally responsible ways. The concept concerns the efforts and responsibility of a society in terms of mitigation policies. Sustainable urban forms are the physical dimensions of socially desired urban and community physical forms. A desired physical form should promote a sense of community, safety, health, and place attachment, among other environmental objectives.

Table 1. Concepts of social sustainability and their functions and practices.

\begin{tabular}{|c|c|c|c|}
\hline Concept & Theoretical Premise & Ma & Components \\
\hline 1. Safety & $\begin{array}{l}\text { Risk is the ontological foundation of the social } \\
\text { sustainability framework. Safety and security for } \\
\text { humans and non-humans is the fundamental } \\
\text { requirement of sustainability and social sustainability }\end{array}$ & a. & $\begin{array}{l}\text { Adaptation measures in } \\
\text { order to cope with risk } \\
\text { and uncertainties } \\
\text { Urban vulnerability matrix: } \\
\text { understanding the social } \\
\text { and demographic } \\
\text { dimensions of risk }\end{array}$ \\
\hline 2. Equity & $\begin{array}{l}\text { Social, economic, and environmental injustice pose risk } \\
\text { to society as well as to the efforts of coping with climate } \\
\text { change threats and uncertainties. } \\
\text { More just policies and less inequality reduce the } \\
\text { alienation of people from their living spaces, enhance } \\
\text { their ability to cope with vulnerabilities, and foster the } \\
\text { development of feasible environmental objectives. }\end{array}$ & & $\begin{array}{l}\text { Recognition } \\
\text { Redistribution } \\
\text { Participation }\end{array}$ \\
\hline 4. Sustainable urban forms & $\begin{array}{l}\text { Physical urban form is crucial for achieving } \\
\text { sustainability, safety, and social agendas. }\end{array}$ & $\begin{array}{l}\text { a. } \\
\text { b. } \\
\text { c. } \\
\text { d. } \\
\text { e. } \\
\text { f. } \\
\text { g. } \\
\text { h. }\end{array}$ & $\begin{array}{l}\text { Compactness, } \\
\text { Mixed land uses, } \\
\text { Diversity, } \\
\text { Clean energy, } \\
\text { Passive solar design, } \\
\text { Greening, } \\
\text { Sustainable transport, } \\
\text { Renewal and utilization }\end{array}$ \\
\hline
\end{tabular}

Author Contributions: Efrat Eizenberg and Yosef Jabareen conceived, designed, and wrote together this paper.

Conflicts of Interest: The authors declare no conflict of interest.

Funding: This research was funded by ISF-Israel Science Foundation.

\section{References}

1. Constance, L.-T. Global Warming and Sociology. Curr. Sociol. 2008, 56, 445-466.

2. Grundmann, R.; Stehr, N. Climate Change: What Role for Sociology? A Response to Constance Lever-Tracy. Curr. Sociol. 2010, 58, 897-910. [CrossRef]

3. Vinthagen, S. Ten theses on why we need a "Social Science Panel on Climate Change". ACME Int. J. Crit. Geogr. 2013, 12, 155-176.

4. Jabareen, Y. The Risk City: Cities Countering Climate Change: Emerging Planning Theories and Practices around the World; Springer: New York, NY, USA, 2015.

5. Eizenberg, E.; Shilon, M. Pedagogy for the new planner: Refining the qualitative toolbox. Environ. Plan. $B$ 2016, 43, 1118-1135. [CrossRef]

6. Hopwood, B.; Mellor, M.; O’Brien, G. Sustainable Development: Mapping Different Approaches. Sustain. Dev. 2005, 13, 38-52. [CrossRef] 
7. Featherstone, D. The contested politics of climate change and the crisis of neo-liberalism. ACME Int. J. Crit. Geogr. 2013, 12, 44-64.

8. Littig, B.; Grießler, E. Social sustainability: A catchword between political pragmatism and social theory. Int. J. Sustain. Dev. 2005, 8, 65-79. [CrossRef]

9. Åhman, H. Social sustainability—Society at the intersection of development and maintenance. Local Environ. 2013, 18, 1153-1166. [CrossRef]

10. Axelsson, R.; Angelstam, P.; Degerman, E.; Teitelbaum, S.; Andersson, K. Social and Cultural Sustainability: Criteria, Indicators, Verifier Variables for Measurement and Maps for Visualization to Support Planning. Ambio 2013, 42, 215-228. [CrossRef] [PubMed]

11. Vallance, S.; Perkins, H.C.; Dixon, J.E. What Is Social Sustainability? A Clarification of Concepts. Geoforum 2011, 42, 342-348. [CrossRef]

12. Grieller, E.; Littig, B. Soziale Nachhaltigkeit; Arbeiterkammer Wien, Ed.; Informationen zur Umweltpolitik 160: Wien, Austria, 2004.

13. Boström, M. A missing pillar? Challenges in theorizing and practicing social sustainability. Sustain Sci. Pract. Pol. 2012, 8, 3-14.

14. Davidson, M. Social sustainability: A potential for politics? Local Environ. 2009, 14, 607-619. [CrossRef]

15. Beck, U. Risk Society: Towards a New Modernity; Sage: London, UK, 1992.

16. Beck, U.; Giddens, A.; Lash, S. Reflexive Modernization: Politics, Tradition, and Aesthetics in Modern Social Order; Polity: Cambridge, UK, 1994.

17. Beck, U. Power in the Global Age; Polity Press: Cambridge, UK, 2005.

18. Office of the Deputy Prime Minister. Sustainable Communities: Building for the Future; Office of the Deputy Prime Minister: London, UK, 2003.

19. Dempsey, N.; Bramley, G.; Power, S.; Brown, C. The Social Dimension of Sustainable Development: Defining Urban Social Sustainability. Sustain. Dev. 2011, 19, 289-300. [CrossRef]

20. Dempsey, N.; Brown, C.; Bramley, G. The Key to Sustainable Urban Development in UK Cities? The Influence of Density on Social Sustainability. Prog. Plan. 2012, 77, 89-141. [CrossRef]

21. Jabareen, Y.R. Sustainable Urban Forms Their Typologies, Models, and Concepts. J. Plan. Educ. Res. 2006, 26, 38-52. [CrossRef]

22. Coleman, J.S. Social capital in the creation of human capital. Am. J. Sociol. 1988, 94, S95-S120. [CrossRef]

23. Fainstein, S. The Just City; Cornell University Press: Ithaca, NY, USA, 2010.

24. Boonstra, B.; Boelens, L. Self-organisation in urban development: Towards a new perspective on spatial planning. Urban Res. Pract. 2010, 4, 99-122. [CrossRef]

25. McCann, E. Collaborative Visioning or Urban Planning as Therapy? The Politics of Public-Private Policy Making. Prof. Geogr. 2001, 53, 207-218. [CrossRef]

26. Agyeman, J. Sustainable Communities and the Challenge of Environmental Justice. 2005. Available online: https:/ / www.google.com/books?hl=en\&lr=\&id=V8cVCgAAQBAJ\&oi=fnd\&pg=PP9\&dq=sustainable+ communities\&ots=AAjCTxatxn\&sig=DeGZpUbN-pY_wHK8i7QJn2KnKpM (accessed on 9 August 2016).

27. Roseland, M. Toward Sustainable Communities: Solutions for Citizens and Their Governments. 2012. Available online: https:/ / www.google.com/books?hl=en\&lr=\&id=vZ3zAgAAQBAJ\&oi=fnd\&pg=PR6\& $\mathrm{dq}=$ sustainable+communities\&ots=ATkRycNKxX\&sig=npe7nuMAk28icRd8Z2_w9BCs3EU (accessed on 9 August 2016).

28. Innes, J.E.; Booher, D.E. Indicators for Sustainable Communities: A Strategy Building on Complexity Theory and Distributed Intelligence. Plan. Theory Pract. 2000, 1, 173-186. [CrossRef]

29. Healey, P. The Communicative Turn in Planning Theory and Its Implications for Spatial Strategy Formation. Environ. Plan. B Plan. Des. 1996, 23, 217-234. [CrossRef]

30. Innes, J.E.; Booher, D.E. Reframing Public Participation: Strategies for the 21st Century. Plan. Theory Pract. 2004, 5, 419-436. [CrossRef]

31. Flyvbjerg, B.; Richardson, T. Planning and Foucault: In Search of the Dark Side of Planning Theory. In Planning Futures: New Directions for Planning Theory; Routledge: London, UK; New York, NY, USA, 2002.

32. Rydin, Y.; Pennington, M. Public Participation and Local Environmental Planning: The Collective Action Problem and the Potential of Social Capital. Local Environ. 2000, 5, 153-169. [CrossRef]

33. Jabareen, Y. Building Conceptual Framework: Philosophy, Definitions and Procedure. Int. J. Qual. Methods $2009,8,49-62$. 
34. Blumenfeld, H. Criteria for judging the quality of the urban environment. In The Quality of Urban Life; Schmandt, H.J., Bloomberg, W., Eds.; Sage Publications: Beverly Hills, CA, USA, 1969; pp. 137-163.

35. Giddens, A. New Rules of Sociological Method; Hutchinson: London, UK, 1976.

36. Häkli, J. Geographies of rust. In Social Capital and Urban Networks of Trust; Häkli, J., Minca, C., Eds.; Ashgate: Farnham, UK, 2009; pp. 13-35.

37. IPCC (Intergovernmental Panel on Climate Change). Chapter 8: Urban areas. In Climate Change 2014: Impacts, Adaptation, and Vulnerability; Cambridge University Press: Cambridge, UK, 2014; p. 6.

38. IPCC (Intergovernmental Panel on Climate Change). Managing the Risks of Extreme Events and Disasters to Advance Climate Change Adaptation. A Special Report of Working Groups I and II of the Intergovernmental Panel on Climate Change; Field, C.B., Barros, V., Stocker, T.F., Qin, D., Dokken, D.J., Ebi, K.L., Mastrandrea, M.D., Mach, K.J., Plattner, G.-K., Allen, S.K., et al., Eds.; Cambridge University Press: Cambridge, UK; New York, NY, USA, 2012.

39. Jabareen, Y. Planning for Countering Climate Change: Lessons from the Recent Plan of New York City-PlaNYC 2030. Int. Plan. Stud. 2013, 18, 221-242. [CrossRef]

40. Adger, W.N. Scales of governance and environmental justice for adaptation and mitigation of climate change. J. Int. Dev. 2001, 13, 921-931. [CrossRef]

41. Kasperson, R.E.; Kasperson, J.X. Climate Change, Vulnerability and Social Justice; Stockholm Environment Institute: Stockholm, Swden, 2001.

42. O’Brien, K.; Leichenko, R.; Kelkar, U.; Venema, H.; Aandahl, G.; Tompkins, H.; Javed, A.; Bhadwal, S.; Barg, A.; Nygaard, L.P.; et al. Mapping vulnerability to multiple stressors: Climate change and globalization in India. Glob. Environ. Chang. 2004, 14, 303-313. [CrossRef]

43. Jabareen, Y. A New Conceptual Framework for Sustainable Development. Environ. Dev. Sustain. 2008, 10, 179-192. [CrossRef]

44. Davies, M.; Guenther, B.; Leavy, J.; Mitchell, T.; Tanner, T. Climate Change Adaptation, Disaster Risk Reduction and Social Protection: Complementary Roles in Agriculture and Rural Growth? IDS (Institute of Developing Studies): Brighton, UK, 2008; Available online: http://www.climategovernance.org/docs/SP-CC-DRR_ idsDFID_08final.pdf (accessed on 15 December 2016).

45. IPCC (Intergovemental Panel on Climate Change). Climate Change 2007: Fourth Assessment Report of the Intergovernmental Panel on Climate Change; Cambridge University Press: Cambridge, MA, USA, 2007.

46. Jabareen, Y. Planning the Resilient City: Concepts and Strategies for Coping with Climate Change and Environmental Risk. Cities 2013, 31, 220-229. [CrossRef]

47. Tearfund. Linking Climate Change Adaptation and Disaster Risk Reduction. 2008. Available online: http:/ /www. tearfund.org/webdocs/Website/Campaigning/CCA and DRR web.pdf (accessed on 30 December 2016).

48. EPA (United States Environmental Protection Agency). Our Built and Natural Environments: A Technical Review of the Interactions Between Land Use, Transportation, and Environmental Quality; EPA 231-R-01-002; EPA: Washington, DC, USA, 2001. Available online: http:/ / www.smartgrowth.org/ (accessed on 30 December 2016).

49. Newman, P.; Kenworthy, J. Gasoline consumption and cities: A comparison of US cities with a global survey. J. Am. Plan. Assoc. 1989, 55, 23-37. [CrossRef]

50. Stymne, S.; Jackson, T. Intra-generational equity and sustainable welfare: A time series analysis for the UK and Sweden. Ecol. Econ. 2000, 33, 219-236. [CrossRef]

51. Adger, W.N.; Agrawala, S.; Mirza, M.M.Q.; Conde, C.; O’Brien, K.; Pulhin, J.; Pulwarty, R.; Smit, B.; Takahashi, K. Assessment of adaptation practices, options, constraints and capacity. In Climate Change 2007: Impacts, Adaptation and Vulnerability. Contribution of Working Group II to the Fourth Assessment Report of the Intergovernmental Panel on Climate Change; Parry, M.L., Canziani, O.F., Palutikof, J.P., van der Linden, P.J., Hanson, C.E., Eds.; Cambridge University Press: Cambridge, UK, 2007; pp. 717-743.

52. Van, U.-P.; Senior, M. The contribution of mixed land uses to sustainable travel in cities. In Achieving Sustainable Urban Form; Williams, K., Burton, E., Jenks, M., Eds.; E \& FN Spon: London, UK, 2000; pp. 139-148.

53. Mohai, P.; Pellow, D.; Roberts, J.T. Environmental Justice. Ann. Rev. Environ. Res. 2009, 34, 405-430. [CrossRef]

54. Blaikie, P.; Cannon, T.; Davis, I.; Wisner, B. At Risk: Natural Hazards, People's Vulnerability, and Disasters; Routledge: London, UK, 1994.

55. Ojerio, R.; Moseley, C.; Lynn, K.; Bania, N. Limited Involvement of Socially Vulnerable Populations in Federal Programs to Mitigate Wildfire Risk in Arizona. Nat. Hazards Rev. 2010, 12, 28-36. [CrossRef] 
56. Cutter, S.L.; Boruff, B.J.; Shirley, W.L. Social Vulnerability to Environmental Hazards. Soc. Sci. Q. 2003, 84, 242-261. [CrossRef]

57. Agyeman, J.; Bullard, R.D.; Evans, B. Exploring the nexus: Bringing together sustainability, environmental justice and equity. Space Polity 2002, 6, 77-90. [CrossRef]

58. Satterthwaite, D. Climate change and urbanization: effects and implications for urban governance. In Proceedings of the UN Expert Group Meeting Population Distribution, Urbanization, Internal Migration Development, New York, NY, USA, 21-23 January 2008.

59. Pulido, L. Rethinking Environmental Racism: White Privilege and Urban Development in Southern California. Ann. Assoc. Am. Geogr. 2000, 90, 12-40. [CrossRef]

60. Dunion, K. Troublemakers-The Struggle for Environmental Justice in Scotland; Edinburgh University Press: Edinburgh, UK, 2003.

61. Solow, R. Sustainability: An Economist's Perspective; The Eighteenth J. Seward Johnson Lecture; Woods Hole Oceanographic Institution: Woods Hole, MA, USA, 1991.

62. Fraser, N. Social Justice in the Age of Identity Politics: Redistribution, Recognition, and Participation. 1996. Available online: http:/ / www.intelligenceispower.com/Important\%20E-mails\%20Sent\%20attachments / Social\%20Justice\%20in\%20the\%20Age\%20of\%20Identity\%20Politics.pdf (accessed on 30 December 2016).

63. Schlosberg, D. Defining Environmental Justice: Theories, Movements, and Nature; Oxford University Press: New York, NY, USA, 2007.

64. Young, I.M. Justice and the Politics of Difference; Princeton University Press: Princeton, NJ, USA, 1990.

65. Carmin, J.; Agyeman, J. (Eds.) Environmental Inequalities beyond Borders: Local Perspectives on Global Injustices; MIT Press: Cambridge, MA, USA, 2011.

66. Holifield, R.; Porter, M.; Walker, G. Introduction: Spaces of environmental justice-Frameworks for critical engagement. In Spaces of Environmental Justice; Holifield, R., Porter, M., Walker, G., Eds.; Wiley-Blackwell: West Sussex, UK, 2010.

67. Jabareen, Y. The right to space production and the right to necessity: Insurgent versus legal rights of Palestinians in Jerusalem. Plan. Theory 2015. [CrossRef]

68. Rpetto, R. (Ed.) The Global Possible: Resources, Development, and the New Century; Yale University Press: New Haven, CT, USA, 1985.

69. CCC (Committee on Climate Change). Building a Low-Carbon Economy-The UK's Innovation Challenge. 2010. Available online: www.theccc.org.uk (accessed on 19 July 2010).

70. Schneider, S.H.; Semenov, S.; Patwardhan, A.; Burton, I.; Magadza, C.H.D.; Oppenheimer, M.; Pittock, A.B.; Rahman, A.; Smith, J.B.; Suarez, A.; et al. Assessing key vulnerabilities and the risk from climate change. In Climate Change 2007: Impacts, Adaptation and Vulnerability. Contribution of Working Group II to the Fourth Assessment Report of the Intergovernmental Panel on Climate Change; Parry, M.L., Canziani, O.F., Palutikof, J.P., van der Linden, P.J., Hanson, C.E., Eds.; Cambridge University Press: Cambridge, UK, 2007; pp. 779-810.

71. Abbott, J. Understanding and managing the unknown: The nature of uncertainty in planning. J. Plan. Educ. Res. 2005, 24, 237-251. [CrossRef]

72. Vellinga, P.; Marinova, N.A.; van Loon-Steensma, J.M. Adaptation to Climate Change: A Framework for Analysis with Examples from the Netherlands. Built Environ. 2009, 35, 452-470. [CrossRef]

73. Priemus, H.; Rietveld, P. Climate change, flood risk and spatial planning. Built Environ. 2009, 35, 425-431. [CrossRef]

74. Alberti, M.; Marzluff, J.; Shulenberger, E.; Bradley, G.; Ryan, C.; Zumbrunnen, C. Integrating Humans into Ecology: Opportunities and Challenges for Urban Ecology. BioScience 2003, 53, 1169-1179. [CrossRef]

75. Timothy, B.; Kristy, M. Ecology of Place: Planning for Environment, Economy, and Community; Island Press: Washington, DC, USA, 1997.

76. Hagen, B. The Role of Planning in Minimizing the Negative Impacts of Global Climate Change. Urban Plan. 2016, 1, 13-24. [CrossRef]

77. Cervero, R. The Transit Metropolis: A Global Inquiry; Island Press: Washington, DC, USA, 1998.

78. Cervero, R. Coping with Complexity in America's Urban Transport Sector. In Proceedings of the 2nd International Conference on the Future of Urban Transport, Göteborg, Sweden, 22-24 September 2003.

79. Jenks, M. The acceptability of urban intensification. In Achieving Sustainable Urban Form; Williams, K., Burton, E., Jenks, M., Eds.; E \& FN SPON: London, UK, 2000. 
80. Wheeler, S.M. Constructing sustainable development/safeguarding our common future: Rethinking sustainable development. J. Am. Plan. Assoc. 2002, 68, 110-111.

81. Parker, T. The Land Use-Air Quality Linkage: How Land Use and Transportation Affect Air Quality; California Air Resources Board: Sacramento, CA, USA, 1994.

82. Thorne, R.; Filmer-Sankey, W. Transportation. In Sustainable Urban Design; Randall, T., Ed.; Spon Press: London, UK, 2003; pp. 25-32.

83. Turner, S.R.S.; Murray, M.S. Managing growth in a climate of urban diversity: South Florida's Eastward ho! Initiative. J. Plan. Educ. Res. 2001, 20, 308-328. [CrossRef]

84. Jacobs, J. The Death and Life of Great American Cities; Random House: New York, NY, USA, 1961.

85. Owens, S. Energy, environmental sustainability and land-use planning. In Sustainable Development and Urban Form; Michael, B., Ed.; Pion: London, UK, 1992; pp. 79-105.

86. Yannis, S. Living with the city: Urban design and environmental sustainability. In Environmentally Friendly Cities; Eduardo, M., Yannas, S., Eds.; James \& James: London, UK, 1998; pp. 41-48.

87. Beatley, T. Green Urbanism: Learning from European Cities; Island Press: Washington, DC, USA, 2000.

88. Beer, A.; Delshammar, T.; Schildwacht, P. A changing understanding of the role of greenspace in high-density housing: A European perspective. Built Environ. 2003, 29, 132-143. [CrossRef]

89. CCC (Committee on Climate Change). How Well Prepared Is the UK for Climate Change? 2010. Available online: http:/ / www.theccc.org.uk (accessed on 16 September 2010).

90. Bulkeley, H.; Newell, P. Governing Climate Change; Routledge: London, UK; New York, NY, USA, 2010.

91. Naukowy, R. User-Driven Information System Development; Studia Ekonomiczne; University of Economics in Katowice: Katowice, Poland, 2013; pp. 145-152. Available online: http:/ /www.ue.katowice.pl/fileadmin/ _migrated/content_uploads/13_W.Wolny_Prosumption....pdf (accessed on 30 December 2016).

92. Ritzer, G. (Ed.) McDonaldization: The Reader; Pine Forge Press: Chicago, IL, USA, 2009.

93. Ritzer, G.; Jurgenson, N. Production, Consumption, Prosumption The nature of capitalism in the age of the digital 'prosumer'. J. Consum. Cult. 2010, 10, 13-36. [CrossRef]

94. Gibson-Graham, J.K. A Postcapitalist Politics; University of Minnesota Press: Minneapolis, MN, USA, 2006.

95. Sennett, R. Together: The Rituals, Pleasures and Politics of Cooperation; Yale University Press: London, UK, 2012.

96. Negri, A.; Hardt, M. Commonwealth; Stock: Cambridge, MA, USA, 2012.

97. Gibson-Graham, J.K.; Roelvink, G. Social innovation for community economies. In Social Innovation and Territorial Development; Routledge: London, UK, 2009; pp. 25-37.

98. Eizenberg, E. Actually existing commons: Three moments of space of community gardens in New York City. Antipode 2012, 44, 764-782. [CrossRef]

99. Feenstra, G.W. Local food systems and sustainable communities. Am. J. Altern. Agric. 1997, 12, $28-36$. [CrossRef]

100. Morgan, K. Feeding the city: The challenge of urban food planning. Int. Plan. Stud. 2009, 14, 341-348. [CrossRef]

101. Nikolaidou, S.; Klöti, T.; Tappert, S.; Drilling, M. Urban Gardening and Green Space Governance: Towards New Collaborative Planning Practices. Urban Plan. 2016, 1, 5-19. [CrossRef]

102. Defilippis, J. Unmaking Goliath: Community Control in the Face of Global Capital; Routledge: London, UK, 2004.

103. Paavola, J.; Adger, W.N. Fair adaptation to climate change. Ecol. Econ. 2006, 56, 594-609. [CrossRef]

104. De Geus, M. Ecological Utopias: Envisioning the Sustainable Society; International Books: Utrecht, The Netherlands, 1999.

(C) 2017 by the authors; licensee MDPI, Basel, Switzerland. This article is an open access article distributed under the terms and conditions of the Creative Commons Attribution (CC-BY) license (http:/ / creativecommons.org/licenses/by/4.0/). 